\title{
Opportunities for Mobilizing Recalcitrant Phosphorus-A Review
}

\author{
Narendra Kumar Yadav ${ }^{*}$ and Rajat Kumar Parit ${ }^{2 *}$ \\ Department of Soil Science, Assam Agricultural University, Jorhat - 785013, India \\ *Corresponding author
}

\section{Keywords}

Recalcitrant phosphorus, Phosphorus mobilization, Phytase, Pressmud, Soil enzyme activity

\section{Article Info}

\section{Accepted:}

08 January 2020

Available Online:

10 February 2020
Phosphorus is perhaps, amongst all the plant nutrients, the one with the most limited bioavailability in soils (approximately $6 \%$ of total soil $\mathrm{P}$ is readily available (Bray's \& Olsen's P). 80 \% of phosphorus is fixed by primary minerals, precipitate, adsorbed or organically complex form. Phosphorus fertilizer is usually applied in excess of plant requirement and accumulates in soils. As soils are complex and diverse chemical, biochemical and biological systems, strategies to access recalcitrant soil $\mathrm{P}$ are often inefficient, case specific and inconsistently applicable in different soils. Under acidic condition, amendment (pressmud \& lime) increases the availability of phosphorus. Organic matter application in soil decreases the Al-P, Fe-P \&Ca-P in soil and increase available P in soil solution. The application of phytase in combination with manure substantially improves soil biological activities as well as better nutrient supply to crop. Finding a near universal or at least widely applicable solution to the inefficiency in agricultural $\mathrm{P}$ use by plants is an important unsolved problem that has been under investigation for more than half a century.

\section{Introduction}

Historically, agricultural strategies to cope with the large phosphorus (P) fixing capacity of many soils have relied on saturating the system with $\mathrm{P}$ in the form of fertilizer, derived from non-renewable rock phosphates, to maintain plant-optimum $\mathrm{P}$ concentrations in soil solution (Fox and Kamprath1970). In some countries, long term fertilizer applications to meet plant needs have led to a build-up of a legacy soil P 'bank', which is largely unavailable to plants (Kamprath, 1967). Recent scientific efforts have been directed toward increasing the plan availability of this legacy soil $\mathrm{P}$ and enabling an efficient agronomic use of this important $\mathrm{P}$ reserve. But, how likely is legacy soil $\mathrm{P}$ to be a key source of $\mathrm{P}$ to sustain agricultural production? For how many growing seasons would legacy soil $\mathrm{P}$ be able to sustain crop production and what yields may be expected? What is our most promising and sustainable agro-ecological innovations to accomplish 
this?. Modern agricultural dependence on non-renewable natural resources, namely $\mathrm{P}$ fertilizers and fossil fuels, is problematic. However, while renewable alternatives to fossil fuels are available, there are still no renewable alternative sources of fertilizer $\mathrm{P}$ to rock phosphate mining (Cordell et al., 2009). As rock phosphate mineral resources decline, phosphate fertilizers will inevitably become a scarce, and consequently a costly input, with severe effects on agricultural production and food security (Abelson 1999; Cordell et al., 2009). Additionally, there is the issue of volatility in rock phosphate supply and the related price oscillations, like the recent sharp increase in price which occurred in 2008 with direct impact on the market value of $P$ fertilizers and in the FAO food price index (Cordell and White, 2014). Most of the known reserves of rock phosphate are present in Morocco (74\%) while Europe has virtually no rock phosphate remaining, and therefore geopolitical issues will be increasingly influential in future $\mathrm{P}$ production. Improving $\mathrm{P}$ cycling in soils and using recycled $\mathrm{P}$ fertilizer sources are not likely to be complete solutions to a future $\mathrm{P}$ crisis, but are key contributors to delaying and reducing the impact of a P scarcity scenario (Stutter et al., 2012). Model simulations show that the residual soil $\mathrm{P}$ pool may play a role in reducing global $\mathrm{P}$ fertilizer use by up to $50 \%$ by 2050 , in relation to other estimates that do not consider the plant use of soil fixed $\mathrm{P}$ (Sattari et al., 2012). Here we argue that an even larger reduction in $\mathrm{P}$ fertilizer input could be accomplished if appropriate technologies were applied in mobilizing recalcitrant forms of soil $P$ currently not considered in $\mathrm{P}$ use models, and that represent a legacy from historic fertilizer inputs.

\section{How much soil phosphorus can potentially be mobilized?}

The amount of $\mathrm{P}$ that can be mobilized by different strategies is dependent on the abundance and liability of the targeted chemical $\mathrm{P}$ species in each soil environment. We have studied soil 31P-NMR data from scientific literature (258 different soils from 41 publications) reporting quantitative speciation of orthophosphate, phosphate monoesters and phosphate diesters groups. The NMR method is usually performed with soil $\mathrm{NaOH}$-EDTA extracts and examines the chemical structure of alkali soluble $\mathrm{P}$ species, which corresponds on average to $55 \%$ of the total soil $\mathrm{P}$ (mined literature). This is a strong extraction process that does not reflect bioavailable $\mathrm{P}$ in soils. To choice of using 31P-NMR data in this analysis, in detriment of other methods was to evaluate stocks of different $\mathrm{P}$ chemical species, and their potential future sustainable use. To estimate the agronomic value of the soil $\mathrm{P}$, these concentrations were scaled up into total $\mathrm{P}$ stocks ( $\mathrm{kg} \mathrm{P}$ ha-1) in the first $15 \mathrm{~cm}$ depth of soil. Across all samples, the orthophosphate pool accounted for approximately $57 \%$ of the $\mathrm{NaOH}-\mathrm{EDT}$ A extractable total $\mathrm{P}$, while the monoester $\mathrm{P}$ pool accounted for approximately $33 \%$.

This indicates that our strategies for mobilizing soil $\mathrm{P}$ for plant nutrition should be focused mainly on the adsorbed and precipitated forms of orthophosphate and on the mineralization of monoester organic $\mathrm{P}$ forms like inositol phosphates. The potential of the use of monoester $\mathrm{P}$ is slightly greater for grasslands than for arable soils. However, this analysis is only sufficient to demonstrate that there is huge potential to mobilise soil $\mathrm{P}$ for future agronomic use.

\section{Approaches and technologies for sustainably increasing recalcitrant soil phosphorus bioavailability}

A sustainable agricultural approach for facing a future rock phosphate shortage should include the unlocking of legacy soil $\mathrm{P}$, in parallel to reducing $\mathrm{P}$ fertilizer load, and 
increasing the use of recycled $\mathrm{P}$ sources. The most relevant question is which technologies will ultimately be the most suitable for increasing recalcitrant soil $\mathrm{P}$ bioavailability? The first obvious strategy to increase the use of the soil residual $\mathrm{P}$ 'bank', involves reducing $\mathrm{P}$ fertilizer application rates and allowing adsorbed and precipitated $\mathrm{P}$ to restore to equilibrium after $\mathrm{P}$ depletion (Menezes- Blackburn et al., 2016c). Nevertheless, this strategy would at some point sacrifice agricultural productivity and it is only suitable for the initial depletion of extremely $\mathrm{P}$ rich soils. For most agricultural soils under a depletion scenario, soil solution $P$ levels would decrease below optimal levels for plant growth, and therefore coupled strategies are needed to replenish soil solution $\mathrm{P}$ by actively promoting $\mathrm{P}$ desorption, solubilisation and mineralization. Sacrificing productivity is unacceptable and incompatible with the need of feeding an ever growing world population. The focus for low $\mathrm{P}$ soils such as these is on increasing $\mathrm{P}$ fertilizer use efficiency and preventing the accumulation of recalcitrant soil $\mathrm{P}$. Crop rotation using plant species with the ability to scavenge soil recalcitrant $\mathrm{P}$, adapted to low soil $\mathrm{P}$ availability and high $\mathrm{P}$ fixing capacity conditions, have been suggested as a means of enhancing the solubility of less labile $\mathrm{P}$ forms and increasing $\mathrm{P}$ cycling (Almeida and Rosolem2016), with the intention of improving $\mathrm{P}$ availability for subsequent cash crops. Furthermore, the use of cover crops in no-till farming system has been shown as a good strategy to reduce the soil $\mathrm{P}$ adsorption capacity, when compared to conventional system. Several different approaches are available to improve $\mathrm{Po}$ and $\mathrm{Pi}$ availability and improve Po turnover.

Enhancing the solubility of soil Po by using amendments that alter surface properties of soil particles (Guppy et al., 2005), adding oxidizing agents, increased root exudation of organic acids, managing crop rotation and tillage, and increasing aeration and microbial respiration in soils may improve the availability of $\mathrm{P}$, but may also have undesirable impacts on the carbon cycle. These include increasing organic matter loss and $\mathrm{CO} 2$ emission into the atmosphere. Little is known about whether carbon loss would be greater or less than the equivalent impact of $\mathrm{P}$ fertilizer application. As climate change represents another global threat for future agriculture sustainability, then innovations to improve soil $\mathrm{P}$ availability ideally should not induce increases in greenhouse gas emissions. Acting independently of the soils C:P stoichiometry, enzyme related technologies can release Pi from soil Po without affecting stabilized organic carbon and therefore appear to be a favourable approach to mobilizing a significant fraction of the residual Po without causing loss of carbon to the atmosphere (Trouillefou et al., 2015). Soil P mobilization solutions should be targeted in the rhizosphere to guarantee that most of the mobilized P is taken-up by plants (Giles et al., 2017, 2016; Stutter et al., 2012). Many plantevolved mechanisms to cope with $P$ deficiency have been described, including modified root architecture, abundance of root hairs, root depth distribution, and $\mathrm{P}$ mobilisation by root exudation of enzymes, organic acids, siderophores, surfactants and microbial growth stimulants (Brown et al., 2013; Hinsinger2001; Richardson et al., 2009; Vance et al., 2003).

There is a general assumption in the scientific literature that after continuous selection of crop lineages under $\mathrm{P}$ sufficient conditions, modern cultivars have become 'lazy' in scavenging recalcitrant soil $\mathrm{P}$, meaning that $\mathrm{P}$ mobilizing traits have become either lost or are not sufficiently expressed in most commercial plant varieties (Menezes Blackburn et al., 2016b). Some of these plant mechanisms can still be widely enhanced in 
crops either by selective breeding or by genetic modification (Richardson et al., 2009) in order to develop genotypes which can cope with reduced $\mathrm{P}$ inputs. Similar, and sometimes more specialized, soil $\mathrm{P}$ scavenging traits can be found in microbes. The genetic modification of plants to express microbial traits, such as root exudation of appropriate enzymes and organic acids, is in theory a good approach for mobilizing soil fixed P (Richardson et al., 2009).

The optimum approach may not be to directly mobilize soil $\mathrm{P}$ at all, but to reduce plant requirements for high $\mathrm{P}$ availability in soils. A promising biotechnological approach derives from genetic studies to develop crops with reduced phosphate accumulation in the form of phytate in grains (Raboy2001, 2002). On the other hand, reducing phytate levels in seeds may have unintended consequences for germination and seedling vigour. However, a reduction in plant requirements for high $\mathrm{P}$ availability in soils would allow productivity to be maintained at a reduced $\mathrm{P}$ fertilizer input, depleting available $\mathrm{P}$ and reversing the equilibrium towards a natural and gradual mobilization of fixed soil $\mathrm{P}$ by crops.

Inoculating the soil with microbes screened for traits that favour the efficient mobilization of recalcitrant $\mathrm{P}$ has been widely proposed, and some phosphobacteria and mycorrhizal inoculants are already commercially available (Owen et al., 2015). Recent developments have demonstrated that using phosphobacteria inoculants along with their grazers (nematodes) could significantly increase available $\mathrm{P}$ and plant $\mathrm{P}$ uptake (Irshad et al., 2012).

Fertilizer application technologies such as rate, frequency, depth and fertilizer placement relative to seed position have an important effect on $\mathrm{P}$ uptake efficiency, and are dependent on both plant and soil type. The fertilizer should be applied where and when the plants need it; applying $\mathrm{P}$ fertilizer to the whole topsoil is not an efficient approach and the rhizosphere should ideally be targeted.).

Phosphorus availability includes the rate and extent of mineralization, soil $\mathrm{P}$ retention due to mineral formation and availability coefficient for organic-P. Phosphorus mineralization started quickly after one week of aerobic and nearly saturated incubation with no indication of immobilization even during initial incubation period. A large amount of Olsen $\mathrm{P}$ accumulated periodically in the equilibrium solution after four weeks, followed by a period of gradual increase up to the termination of 12 weeks incubation. Olsen $\mathrm{P}$ in the soil under control treatment (no pi and no pm) remained relatively constant over the length of experiment. However, there were clear differences in Olsen $\mathrm{P}$ accumulation over time with PM application at both application rates that resulted in net $\mathrm{P}$ mineralization. Significant improvement in Olsen $\mathrm{P}$ accumulation due to PM application in Pi treated and untreated soil was obtained. Following the application of PM @ 0.5 and 1 $\%$, the soil solution $\mathrm{P}$ concentration increased significantly by 13.7 and $24.6 \%$ in the soil. The increase in Olsen $\mathrm{P}$ was expected due to higher $\mathrm{P}$ content $(1.44 \%)$ and narrow $\mathrm{C}: \mathrm{P}$ ratio (30:1) of $\mathrm{PM}$ which facilitated its rapid mineralization and no tie up in the soil. Total $\mathrm{P}$ and $\mathrm{Pi}$ concentration in the PM used in the study were 1.44 and $0.86 \%$, respectively indicating that $59.7 \%$ of fertilizer-P content was inorganic. Pre treatment of $\mathrm{Pi}$ significantly enhanced the Olsen $\mathrm{P}$ accumulation over no $\mathrm{Pi}$ control. Non calcareous soil registered $29.2 \%$ higher Olsen-P concentration than calcareous soil. The application of PM @ 0.5 and 1\% under nearly saturated moisture regime, account for about 12.1 and $11.0 \%$ higher Olsen-P as compared to its application under aerobic soil condition. The liberation of organic acids 
which compete with the orthophosphate ions for the active adsorption sites occurred in greater amounts in the soil incubated under waterlogged conditions as compared to under aerobic ones ( Wang et al., 1967). Saturated conditions enhance the amount of labile $\mathrm{P}$ and concentration $\mathrm{P}$ in the soil solution, by decreasing soil $\mathrm{pH}$ due to carbon di oxide accumulation in the calcareous soils (Yadvinder Singh et al., 1988).

The results of this study corroborate the findings of Kabba and Aulakh (2004) who reported higher $\mathrm{P}$ mineralization from added crop residues at nearly saturated than under upland moisture regime.

The conjoint application of PM and Pi maintained higher Olsen $\mathrm{P}$ concentration as compared to their separate application. The concentration of Olsen $\mathrm{P}$ for calcareous soil ranged from 11.3 to 14.1 and 13.2 to $15.2 \mathrm{mg}$ $\mathrm{P}$ per $\mathrm{kg}$ soil in separate and from 15.9 to 17.7 and 17.2 to $19.2 \mathrm{mg} \mathrm{P}$ per $\mathrm{kg}$ soil in combined application under aerobic and nearly saturated moisture regimes, respectively.

The different lime levels significantly influenced the available $\mathrm{P}$ in the soil (Table$2)$. The highest available $P$ in the soil was recorded with application of lime at 100 per cent LR. The beneficial effect of liming is attributed to decrease in phosphate fixation in the soil due to precipitation of iron and aluminium ions due to liming and breaking of the complex iron and aluminium phosphates and making phosphate available in the form of monocalcium phosphate (Solanky et al., 1971). The increase in availability of phosphorus upon liming might also be attributed to accelerated rate of organic matter decomposition due to increased biological activity of soil (Haynes 1992).

The application of different level of phosphorus significantly affected availability of the phosphorus in the soil. The application of phosphorus at P3 level recorded maximum available phosphorus in the soil. Phosphorus application in combination with lime significantly increases availability of phosphorus in the soil. Liming reduces the activity of iron and aluminium hydroxide and brings phosphorus to calcium monophosphate form therefore increasing available phosphorus status due to lime application was understandable (Dixit and Sharma 2003).

Results revealed that the mean Al-P content in soil increased with increasing levels of $\mathrm{P}$ application (Table-3). However, the mean Al$\mathrm{P}$ content decreased with the increasing levels of organic residue during the incubation period. Interaction between added $\mathrm{P}$ and organic residue also had a significant effect on Al-P content in the soil. It is also evident that the data on Al-P contents in soil increased significantly due to increasing time interval from 6 to 12 months.

The result showed that during incubation, the Ca-P content in soil decreased with increasing level of $\mathrm{P}$ application (Table 4). Levels of organic residue also significantly affected the $\mathrm{Ca}-\mathrm{P}$ content in soil during incubation. The mean values of $\mathrm{Ca}-\mathrm{P}$ content decreased from 202 to $174 \mathrm{mg} \mathrm{P} \mathrm{kg}^{-1}$ with increasing amount of organic residue application. Significantly interaction effects were also observed on $\mathrm{Ca}$ $\mathrm{P}$ content in soil due to levels of added $\mathrm{P}$ and organic residue application. Time interval also had the pronounced effect on the Ca-P content in soil during the present incubation study as evident from greater values of $\mathrm{Ca}-\mathrm{P}$ as the time interval progressed from 6 to 12 months. Interaction effects between time interval and organic residue as well as level of $P$ and time interval were found to be significant.

Data revealed that there was a significant increase in available $\mathrm{P}$ in soil from 17.6 to $20.3 \mathrm{mg} / \mathrm{kg}$ due to addition of phosphorus. Increasing rate of application of organic 
residue also enhanced the available $\mathrm{P}$ from 19.2 to $24.0 \mathrm{mg} / \mathrm{kg}$. The interaction effect between added $\mathrm{P}$ and organic residue was found to be significant. The increasing incubation period from 6 to 12 months also increase the available $\mathrm{P}$. the interaction effect on available $\mathrm{P}$ due to applied $\mathrm{P}$ and incubation time interval also found to be significant and the maximum available $\mathrm{P}(26.8 \mathrm{mg} / \mathrm{kg})$ was recorded with application of phosphorus after one year. The available $\mathrm{P}$ enhanced by the addition of inorganic $\mathrm{P}$ as it increased $\mathrm{P}$ sorption at a higher level of solution $\mathrm{P}$ nut with diminishing increment.

Result revealed that use of phytase and FYM levels increased soil available $\mathrm{P}$ at $50 \%$ flowering stage by $6.0 \mathrm{~kg}$ per ha. Use individual level of phytase in absence of FYM recorded consistent increase in soil available P. However same trend with FYM levels recorded slightly increase in soil available $\mathrm{P}$. Phytase application @ 3600 IU recorded significantly higher soil available $\mathrm{P}$ than rest of the treatment at $50 \%$ flowering while use of $2400 \mathrm{IU}$ phytase obtained higher $\mathrm{P}$ availability. In case of FYM, application @ 5 t/ha reported significantly higher soil available $\mathrm{P}$. interaction effect of phytase application@3600 IU along with 2.5 t/ha FYM recorded significantly higher soil available $\mathrm{P}$ at $50 \%$ flowering. Whereas, conjuctive use of phytase @ $2400 \mathrm{IU}+7.5$ t/ha recorded significantly higher soil available $\mathrm{P}$ at harvest of soybean.

\section{Effect of low-rate commercial humic acid on phosphorus availability}

Soluble $\mathrm{P}$ concentrations were nearly identical between soils prior to fertilization, ranging from 0.1 to $0.2 \mathrm{mg}$ L21). Following fertilization, soluble $\mathrm{P}$ concentrations at 1.9 $\mathrm{cm}$ from the fertilizer band only increased slightly over background concentrations, likely due to $\mathrm{Ca}-\mathrm{P}$ precipitation. Conversely, soluble $\mathrm{P}$ concentrations in the non-calcareous soil increased approximately 400-fold, necessitating very different $\mathrm{y}$-axis scales between graphs for each soil. There were no significant differences ( $\mathrm{P} 1 / 40.05)$ in soluble $\mathrm{P}$ concentrations between HA treatments and the control for any time point after fertilization for either soil. The only substantial difference was at day 4 in the noncalcareous soil, when soluble $\mathrm{P}$ concentrations in both HA treatments were approximately 2.5-fold higher than the control. Although high natural heterogeneity in soluble $\mathrm{P}$ concentrations prevented these differences from being statistically significant, the difference was essentially negated by day 8 and completely negated by day 16, suggesting that if HA had affected soluble $\mathrm{P}$ concentrations, this effect was short lived. Overall, there was a lack of significant differences in soluble $P$ concentrations $1.9 \mathrm{~cm}$ to the side of the band between $\mathrm{HA}$ and control treatments following fertilization in both soils. It had been hypothesized that HA would increase soluble $\mathrm{P}$ concentrations in the calcareous soil because $\mathrm{HA}$ has been shown to decrease precipitation rates of $\mathrm{Ca}-\mathrm{P}$ minerals in solution (Grossl and Inskeep, 1991, 1992; Inskeep and Silvertooth, 1988). For example, $\mathrm{HA}$ at $1 \mathrm{mM}$ of $\mathrm{C}$ has been found to inhibit precipitation of dicalcium phosphate dehydrate and octacalcium phosphate by $72 \%$ and $99 \%$, respectively (Grossl and Inskeep, 1991, 1992). The inhibitory effect of added HA was attributed to adsorption of the HA onto Ca-P surfaces, blocking sites for new crystal growth.

Effect of Organic matter vis-à-vis Humic acid on Phosphorus availability of RiceMustard cropping sequence

Treatments adopted with Rice:

$\mathrm{T} 1=$ Control

$\mathrm{T} 2=\mathrm{FYM}$ at $10 \mathrm{t} / \mathrm{ha}$ as basal

$\mathrm{T} 3=\mathrm{CHA}$ at $1.0 \mathrm{~kg} / \mathrm{ha}$ as basal $\mathrm{T} 4=$

EHA at $1.0 \mathrm{~kg} / \mathrm{ha}$ as basal 
Treatments adopted with mustard:

T1=Control, T2=FYM @ 5 t/ha as basal, T3=CHA@0.5 kg/ha as basal, T4=EHA @ $0.5 \mathrm{~kg} / \mathrm{ha}$ as basal

Effect of FYM @ 5and 2.5 t/ha, commercial and extracted HA @ 0.5 and $2.5 \mathrm{~kg} / \mathrm{ha}$ on rice followed by mustard on available $\mathrm{P}$ In soil (table 7) revealed that irrespective to treatments, the availability of $\mathrm{P}$ increased up to panicle initiation stage and gradually decrease towards harvesting stage of rice. This, in turn, resulted in increased $\mathrm{P}$ uptake by rice.

Highest significant availability of $\mathrm{P}$ was recorded with the treatment of EHA at PI stage followed by FYM and CHA despite at tillering stage $\mathrm{P}$ availability gradually declined from FYM to EHA and CHA as compared to that of control.

This result indicated microbial proliferation of FYM was in faster rate than humic substance resulting in mineralization of organic $\mathrm{P}$ in soil. At harvesting stage EHA resulted highest availability of $\mathrm{P}$ followed by followed by CHA in comparing with control justified the effects of root exudates on microbial activity and nutrient availability in rhizosphere soil. During mustard cultivation, EHA had resulted significantly higher amount of available $\mathrm{P}$ followed by CHA and FYM, respectively as compared to that of control.

Significantly higher rate of $\mathrm{P}$ availability at harvesting stage of rice due to application and organic matter at basal and microbial activity on root exudates (Carvalhais et al., 2011) jointly raised the amount of $P$ throughout the cultivation period of mustard.

\section{Root phenes for enhanced soil exploration and phosphorus acquisition}

Root hairs are particularly important for $\mathrm{P}$ acquisition in non-mycorrhizal plants, since mycorrhizal hyphae fulfill some of the same functions as root hairs. However, genotypic variation in root hair length and density is important for PAE ('P acquisition efficiency) regardless of the mycorrhizal status of the plant (Lynch (2011).

\section{Mobilization of phosphorus by root exudates of sugar beet}

Fig C. shows that the excretion of organic acids as a function of $\mathrm{P}$ status of the plant. It can be seen, that excretion of acids increased with decreasing $\mathrm{P}$ content of the shoots. Oxalic acid is excreted most followed by oxalacetic acid and citric acid. The exudation rate of root tips is three times higher than that of the whole root system.

Fig D. shows that the $\mathrm{P}$ concentration in shaking solution is greatly affected by each of the organic acids. At a carboxylate adsorption more than $10 \mu \mathrm{M} / \mathrm{g}$ soil shows that citric acid has the greatest $\mathrm{P}$ mobilization. Obviously it is not only the exudation rate of organic acids but also the acid spectrum is important for $\mathrm{P}$ mobilization, e.g. citric acid is more effective than the other acids.

Fig.C shows that increasing application of organic acids increased clearly the release of P. Application rates of more than $60 \mu M$ carboxylate $\mathrm{g}^{-1}$ significantly increased $\mathrm{P}$ mobilization. It is seen, that at the same time the $\mathrm{pH}$ is lowered to 3 . It is remarkable that the effect of $\mathrm{P}$ release by acidifying with $\mathrm{HCl}$ is very small and only at $\mathrm{pH}$ values lower than 4. It can be concluded that the organic acids changed the chemistry in the rhizosphere of sugar beet plants and probably mobilized $\mathrm{P}$ at $P$ deficiency levels.

\section{Ruzi grass grown in rotation with soybean increases soil labile phosphorus}

The AER-P concentration was higher $(p<$ 0.05 ) in the 0.00 - to $0.10-\mathrm{m}$ soil layer after 
cropping ruzigrass than after fallowing. The SOM content was higher $(p<0.05)$ to a depth of $0.20 \mathrm{~m}$ in plots where ruzigrass was grown which can result in increased AER-extractable P (Almeida et al., 2003). There was an interaction of broadcast phosphate application and ruzigrass: the total $\mathrm{NaHCO} 3$-extractable $\mathrm{P}$ content $(\mathrm{NaHCO} 3-\mathrm{Pt})$, which is the sum of $\mathrm{Pi}$ and $\mathrm{Po}$ extracted with $\mathrm{NaHCO} 3$, was higher $(p<0.05)$ in the uppermost soil layer after ruzigrass fertilized with TSP than RRP. Merlin et al., (2013) observed an increase in labile fractions of $\mathrm{P}$ after planting ruzigrass, both for AER-extractable $\mathrm{P}$, as well as for inorganic and organic fractions extracted with NaHCO3, just when phosphates were broadcast, but this result was obtained 7 mo after phosphate application. In the present study, phosphates were broadcast 32 mo before soil sampling, and there was no effect of ruzigrass on soil $\mathrm{NaHCO}_{3}-\mathrm{Pi}$ and $\mathrm{NaHCO}_{3}-$ Po. However, the effect of ruzigrass increasing labile $\mathrm{P}$ was only observed when AER-P was added to $\mathrm{NaHCO}_{3}-\mathrm{Pt}$ several researchers argue that AER and $\mathrm{NaHCO}_{3}-$ extractable $\mathrm{P}$ correspond to the same fraction of $\mathrm{P}$ in the soil, corresponding to $\mathrm{P}$ labile in equilibrium with $\mathrm{P}$ in the soil solution (Redel et al., 2007; Pavinato et al., 2009).

Ruzigrass decreased $(p<0.05)$ the soil Residual-P fraction in the 0.10 - to $0.20-\mathrm{m}$ soil layer compared with fallowing (Fig. 2), showing that $\mathrm{P}$ adsorption could be reversed and that $\mathrm{P}$ is not irreversibly fixed even in tropical soils (Syers et al., 2008). Guo and Yost (1998) evaluated $\mathrm{P}$ forms in 14 consecutive corns (Zea mays L.) Crops in rotation with soybean in weathered soils, and they observed that these species were able to access only the most labile P. They were unable to convert the moderately labile fractions into labile fractions, resulting in accumulation of $\mathrm{P}$ in the residual fraction, thus demonstrating the low efficiency at which these species uses $\mathrm{P}$ added to the soil.

\section{Effect of $P$ sources and Dual Inoculation of VAM and rhizobium on phosphorus uptake by green gram}

Three P sources was used Rock phosphate, SSP and mixture (1:1) with and without lime (lime applied 2.5t/ha).

The available $\mathrm{P}$ balance in soil is presented in table 9. The data indicate that the $\mathrm{P}$ balance was greatly influenced by dual inoculation in presence of $\mathrm{P}$ application irrespective of liming. Mobilization of available form of $\mathrm{P}$, probably due to VAM component of dual inoculation seemed to be highest in the treatment receiving SSP source under liming and the order of solubilization was in the treatments : SSP > RP + SSP > RP.

The available $\mathrm{P}$ balance under no liming showed negative values. $\mathrm{P}$ balance $(\mathrm{kg} / \mathrm{ha})=$ (available $\mathrm{P}$ in soil after harvest in $\mathrm{kg} / \mathrm{ha}+\mathrm{P}$ utilized by plant $\mathrm{kg} / \mathrm{ha}$ - initial available $\mathrm{P}$ in soil $\mathrm{kg} / \mathrm{ha}+$ applied in soil $\mathrm{kg} / \mathrm{ha}$ ). This may be due to higher $\mathrm{P}$ utilization than the release of $\mathrm{P}$ from the sources. Higher $\mathrm{P}$ release by the inoculants under liming situation in presence of soluble $\mathrm{P}$ source may be due to priming effect, as a result of which there was increased $\mathrm{P}$ uptake and dry matter yield.

The investigation suggests that dual inoculation with Rhizobium and VAM in organic matter and lime amended acid soil receiving phosphate from a cheaper unavailable source like rock phosphate can improve the availability of $\mathrm{P}$ for green gram crop.

Delineation of phosphate solubilizing bacteria from rhizosphere of different crops of Assam

65 Rhizosphere soils having varied chemical 
properties from four crops (sugarcane, rice, wheat and toria) of Assam were collected for isolation of PSB. PSB were isolated on selective Pikovskaya's solid media containing TCP as phosphate source through serial dilution technique. 29 culture of PSB isolated from 65 rhizosphere soils. On the basis of purity, qualitative observation of clearing zone, 13 isolates were singled out for quantitative estimation of $\mathrm{P}$ solubilization.

The frequency of well recognized PSB colonies that produced clear zone in media ranged from 3.0 to $10.33 \times 10^{6} \mathrm{cfu} / \mathrm{g}$ in rhizosphere of four different crops across the selected sites of Assam (Table 10). PSB population is dependence on physical chemical properties of soil. PSB population is mostly affected by carbon \% of soil. Increase in carbon \% PSB population is also increase.
Maximum population of PSB is found in wheat (PSB28) rhizosphere soil and minimum in rice (PSB25Y) rhizosphere soil. The available $\mathrm{P}$ content in the rhizosphere contributed by about 14\% towards the variation of PSB population irrespective of the crops. In the acid soil of Assam no correlation were found in between the PSB population with respect to other chemical properties.

The solubilization of TCP by 13 PSB isolates was accompanied by a significant drop in $\mathrm{pH}$ after 10 days of incubation (Table 11). It has been well established that the main mechanism of inorganic $\mathrm{P}$ solubilization is through a decrease in $\mathrm{pH}$ (Illmer and Schinner 1992) and alteration of solubility product by acid producing chelates with $\mathrm{Ca}^{+2}$ (Nautiyal et al., 2000).

Table.1 Phosphorus supplying capacity of pressmud amended soil under different moisture regimes

\begin{tabular}{|c|c|c|c|c|c|c|c|c|}
\hline \multirow{3}{*}{$\begin{array}{l}\text { Inorgan } \\
\text { ic } \mathbf{P}(\mathbf{m g} \\
\mathbf{P} / \mathbf{k g})\end{array}$} & \multicolumn{8}{|c|}{ Pressmud level (\%) } \\
\hline & \multicolumn{4}{|c|}{ Aerobic } & \multicolumn{4}{|c|}{ Nearly Saturated } \\
\hline & $\mathbf{0}$ & .5 & \multicolumn{2}{|c|}{ mean } & $\mathbf{0}$ & 0.5 & \multicolumn{2}{|c|}{ mean } \\
\hline & \multicolumn{8}{|c|}{ Calcareous soil } \\
\hline $\mathbf{0}$ & 10.5 & 11.3 & 12.3 & 11.5 & 11.8 & 13.2 & 14.2 & 13.0 \\
\hline 25 & 14.1 & 15.9 & 17.7 & 16.0 & 15.2 & 17.2 & 19.2 & 17.1 \\
\hline \multirow[t]{2}{*}{ Mean } & 12.3 & 13.6 & 15.0 & 13.7 & 13.5 & 15.2 & 16.6 & 15.1 \\
\hline & \multicolumn{8}{|c|}{ Non calcareous soil } \\
\hline $\mathbf{0}$ & 13.7 & 14.7 & 16.3 & 15.0 & 15.0 & 17.2 & 18.7 & 17.0 \\
\hline 25 & 17.8 & 20.6 & 22.9 & 20.4 & 19.4 & 22.7 & 24.7 & 22.2 \\
\hline mean & 15.8 & 17.7 & 19.6 & 17.5 & 17.2 & 20.0 & 21.8 & 19.6 \\
\hline
\end{tabular}

Source: Singh et al., (2010) 
Table.2 Effect of lime on Phosphorus availability

\begin{tabular}{|r|c|c|c|c|}
\hline \multicolumn{4}{|c|}{ Lime level } & \multicolumn{4}{|c|}{ Available P kg/ha } \\
\hline $\mathbf{L}_{\mathbf{0}}$ & $\mathbf{P}_{\mathbf{1}}$ & $\mathbf{P}_{\mathbf{2}}$ & $\mathbf{P}_{\mathbf{3}}$ & Mean \\
\hline $\mathbf{L}_{\mathbf{1}}$ & 7.2 & 7.4 & 7.8 & 7.2 \\
\hline $\mathbf{L}_{\mathbf{2}}$ & 7.7 & 7.9 & 8.5 & 7.9 \\
\hline Mean & 7.0 & 8.3 & 9.0 & 8.4 \\
\hline
\end{tabular}

$\mathrm{L}_{0}=$ no lime, $\mathrm{L}_{1}=50 \%$ of $\mathrm{LR}, \mathrm{L}_{2}=100 \%$ of $\mathrm{LR}$

Source: Patil et al., 2010

$\mathrm{P}_{1}=50 \%$ of $\mathrm{RD}, \mathrm{P}_{2}=100 \%$ of $\mathrm{RD}, \mathrm{P}_{3}=150 \%$ of $\mathrm{RD}$

Table.3 Effect of Phosphorus levels, organic residues and time interval on Al-P (mg P/kg)

\begin{tabular}{|c|c|c|c|c|}
\hline \multirow[t]{2}{*}{ Treatment } & \multicolumn{4}{|c|}{$\begin{array}{l}\text { Al-P(mg P/kg) } \\
\text { Organic residues(g/kg soil) }\end{array}$} \\
\hline & 0 & 2.5 & 5.0 & mean \\
\hline \multicolumn{5}{|c|}{ Phosphorus levels $\left(\mathrm{mg}_{2} \mathrm{O}_{5} / \mathrm{kg}\right)$} \\
\hline 0 & 37.9 & 28.7 & 29 & 31.9 \\
\hline 10 & 41.5 & 29.9 & 28.5 & 33.3 \\
\hline \multicolumn{5}{|c|}{ Time interval (month) } \\
\hline 6 & 27.9 & 23.9 & 26.4 & 26.1 \\
\hline 12 & 51.5 & 34.8 & 31.1 & 39.1 \\
\hline mean & 39.7 & 29.3 & 28.7 & \\
\hline
\end{tabular}

Source: Datta et al., (2014)

Table.4 Effect of Phosphorus levels, organic residues and time interval on Ca-P (mg P/kg)

\begin{tabular}{|c|c|c|c|c|}
\hline \multirow[t]{2}{*}{ Treatment } & \multicolumn{4}{|c|}{$\begin{array}{c}\mathrm{Al}-\mathrm{P}(\mathrm{mg} \mathrm{P} / \mathrm{kg}) \\
\text { Organic residues(g/kg soil) }\end{array}$} \\
\hline & $\mathbf{0}$ & 2.5 & 5.0 & mean \\
\hline \multicolumn{5}{|c|}{ Phosphorus levels $\left(\mathrm{mg}_{2} \mathrm{O}_{5} / \mathbf{k g}\right)$} \\
\hline $\mathbf{0}$ & 202 & 189 & 176 & 188 \\
\hline 10 & 201 & 173 & 173 & 183 \\
\hline \multicolumn{5}{|c|}{ Time interval (month) } \\
\hline 6 & 174 & 175 & 174 & 174 \\
\hline 12 & 229 & 187 & 175 & 197 \\
\hline Mean & 202 & 181 & 174 & \\
\hline
\end{tabular}

Source: Datta et al., 2014 
Table.5 Effect of phosphorus levels, organic residues and time interval on Olsen-P (mg P $/ \mathrm{kg}$ )

\begin{tabular}{|c|c|c|c|c|}
\hline \multirow[t]{2}{*}{ Treatment } & \multicolumn{4}{|c|}{$\begin{array}{c}\text { Olsen } \mathrm{P}(\mathrm{mg} \mathrm{P} / \mathrm{kg}) \\
\text { Organic residues(g/kg soil) }\end{array}$} \\
\hline & 0 & 2.5 & 5.0 & mean \\
\hline \multicolumn{5}{|c|}{ Phosphorus levels $\left(\mathrm{mg} \mathrm{P}_{2} \mathrm{O}_{5} / \mathrm{kg}\right.$ ) } \\
\hline 0 & 16 & 13.9 & 23.1 & 17.7 \\
\hline 10 & 22.5 & 13.5 & 24.8 & 20.3 \\
\hline \multicolumn{5}{|c|}{ Time interval (month) } \\
\hline 6 & 18.5 & 19.8 & 21.1 & 19.8 \\
\hline 12 & 19.7 & 23.8 & 26.8 & 23.4 \\
\hline mean & 19.2 & 17.8 & 24 & \\
\hline
\end{tabular}

Source: Datta et al., 2014

Table.6 Effect of phytase and FYM levels on available P (kg/ha) at 50\% flowering stage of soybean

\begin{tabular}{|c|c|c|c|c|c|}
\hline \multirow{2}{*}{$\begin{array}{l}\text { Phytase level } \\
\text { (IU) }\end{array}$} & \multicolumn{5}{|c|}{ FYM levels (t/ha) } \\
\hline & & 2.5 & 5 & 7.5 & \\
\hline $\mathbf{0}$ & 16.4 & 18.5 & 20.1 & 23 & 19.5 \\
\hline 1200 & 18.4 & 19.6 & 22.9 & 19.6 & 20.2 \\
\hline 2400 & 18.5 & 23.5 & 24.2 & 18 & 21.1 \\
\hline 3600 & 20.5 & 24.8 & 21.4 & 23.9 & 22.6 \\
\hline mean & 18.6 & 21.6 & 22.2 & 21.1 & \\
\hline
\end{tabular}

Table.7 Effect of phytase and FYM levels on available P $(\mathrm{kg} / \mathrm{ha})$ at harvest stage of soybean

\begin{tabular}{|l|c|c|c|c|c|}
\hline $\begin{array}{l}\text { Phytase } \\
\text { level }(\mathbf{I U}\end{array}$ & $\mathbf{0}$ & $\mathbf{2 . 5}$ & $\mathbf{5}$ & $\mathbf{7 . 5}$ & mean \\
\hline $\mathbf{0}$ & 11.9 & 14.4 & 15.9 & 19.9 & 14.5 \\
\hline $\mathbf{1 2 0 0}$ & 13.2 & 14.6 & 17.8 & 18.7 & 16.1 \\
\hline $\mathbf{2 4 0 0}$ & 13.6 & 15.6 & 19.3 & 21.9 & 17.6 \\
\hline $\mathbf{3 6 0 0}$ & 13.7 & 15.2 & 14.5 & 18.5 & 15.6 \\
\hline Mean & 13.1 & 14.9 & 16.9 & 19.8 & \\
\hline
\end{tabular}

Source: Jadhav et al., (2017) 
Table.8 Changes in available $\mathrm{P}_{2} \mathrm{O}_{5}(\mathrm{Kg} / \mathrm{ha})$ in different stages of crop

\begin{tabular}{|c|c|c|c|c|c|c|c|}
\hline \multirow{2}{*}{ Treatments } & \multicolumn{4}{|l|}{ Rice } & \multicolumn{3}{|l|}{ Mustard } \\
\hline & Tillering & PI & Flowering & Harvesting & $\begin{array}{l}\text { Branchin } \\
\text { g }\end{array}$ & Flowering & Harvesting \\
\hline T1 & 26.3 & 39 & 32.1 & 29 & 51.7 & 49.4 & 31.4 \\
\hline T2 & 41.6 & 61.5 & 56.6 & 30.9 & 54.1 & 43.9 & 35.3 \\
\hline T3 & 30.9 & 61.5 & 48.9 & 44.3 & 69.3 & 62.9 & 38.4 \\
\hline T4 & 38.6 & 65.4 & 53.5 & 45.8 & 76 & 74.4 & 56.4 \\
\hline
\end{tabular}

Source: Datta et al., (2017)

Table.9 Average soil organic matter (SOM) levels as affected by ruzigrass grown in the soybean off-season or fallow land, in different soil depths

\begin{tabular}{|l|l|l|}
\hline Soil depth $(\mathbf{m})$ & $\begin{array}{l}\text { SOM }(\mathbf{g} / \mathbf{k g}) \\
\text { Ruzzi grass }\end{array}$ & \multicolumn{1}{c|}{ Fallow } \\
\hline $\mathbf{0 - 0 . 0 5}$ & 20.4 & 15.6 \\
\hline $\mathbf{0 . 0 5 - 0 . 1 0}$ & 14.9 & 12.3 \\
\hline $\mathbf{0 . 1 0 - 0 . 2 0}$ & 13.1 & 10.9 \\
\hline $\mathbf{0 . 2 0 - 0 . 4 0}$ & 12.1 & 11.7 \\
\hline
\end{tabular}

Table.10 Effect of dual inoculation and $\mathrm{P}$ fertilization on available $\mathrm{P}$ balance in soil

\begin{tabular}{|c|c|c|c|}
\hline Treatment & $\begin{array}{c}\text { Soil residual } \\
\text { available } \mathbf{P}(\mathrm{kg} / \mathrm{ha})\end{array}$ & $\begin{array}{l}\text { Available } P \text { utilized } \\
\text { by plant (kg/ha) }\end{array}$ & P balance $(\mathrm{kg} / \mathrm{ha})$ \\
\hline Control & 13.6 & 0.6 & 0.6 \\
\hline LOP1 & 33.2 & 2.1 & 1.6 \\
\hline LOP2 & 29.8 & 1.9 & -2.0 \\
\hline LOP3 & 29.1 & 2.4 & -2.0 \\
\hline LOP1 + i & 30.4 & 3.1 & -0.1 \\
\hline LOP2 + i & 30.2 & 2.6 & -0.8 \\
\hline L0P3 + i & 29.7 & 3.5 & -0.4 \\
\hline L1P1 & 31.4 & 1.8 & -0.4 \\
\hline L1P2 & 35.4 & 3.2 & 5.0 \\
\hline L1P3 & 38.5 & 3.8 & 8.7. \\
\hline L1P1 + i & 34.4 & 5.4 & 6.2 \\
\hline L1P2 + i & 39.4 & 5.9 & 11.6 \\
\hline $\mathrm{LOP3}+\mathrm{i}$ & 36.5 & 5.4 & 8.3 \\
\hline
\end{tabular}


Table.11 PSB population and chemical properties of four different crops rhizosphere

\begin{tabular}{|c|c|c|c|c|}
\hline Rhizosphere of crops & $\begin{array}{c}\text { Clear colony } \\
\text { zone (cfu x } \\
10^{6} \text { per g dry } \\
\text { soil) }\end{array}$ & $\mathbf{P}^{\mathrm{H}}$ & $\begin{array}{c}\text { Org. C } \\
\%\end{array}$ & $\begin{array}{c}\text { Bray's } 1 \mathrm{P}_{2} \mathrm{O}_{5} \\
\text { microgram/gram }\end{array}$ \\
\hline Sugarcane(PSB4Y) & 4.33 & 4.6 & 0.93 & 11.45 \\
\hline Sugarcane(PSB21) & 7.33 & 4.4 & 1.32 & 8.01 \\
\hline Rice (PSB25Y) & 3.33 & 4.55 & 0.36 & 6.30 \\
\hline Rice (PSB49W) & 8.00 & 4.95 & 1.56 & 10.30 \\
\hline Rice $\left(\right.$ PSB $\left._{50)}\right)$ & 4.67 & 5.00 & 0.27 & 8.01 \\
\hline Rice (PSB56) & 6.00 & 4.97 & 1.02 & 8.01 \\
\hline Rice (PSB63) & 8.33 & 4.90 & 1.44 & 22.90 \\
\hline Wheat (PSB24) & 3.00 & 4.59 & 0.75 & 4.58 \\
\hline Wheat (PSB28) & 10.33 & 4.18 & 1.62 & 10.30 \\
\hline Wheat (PSB29Y) & 5.33 & 5.14 & 0.81 & 17.17 \\
\hline Toria (PSB5W) & 3.00 & 4.70 & 0.48 & 10.30 \\
\hline Toria (PSB30Y) & 7.00 & 4.65 & 1.06 & 28.63 \\
\hline Toria (PSB59) & 5.00 & 4.79 & 0.99 & 11.45 \\
\hline
\end{tabular}

Table.12 $\mathrm{P}^{\mathrm{H}}$ drop \& P Solubilization abilities of selected PSB

\begin{tabular}{|c|c|c|}
\hline \multirow[t]{2}{*}{ Rhizosphere crop } & \multicolumn{2}{|c|}{$\begin{array}{c}P^{H} \text { drop and TCP Solubilization in media after } 10 \text { days of } \\
\text { incubation }\end{array}$} \\
\hline & Final $\mathbf{P}^{\mathrm{H}}$ drop & $\%$ phosphate solublization \\
\hline Control & 6.64 & 1.50 \\
\hline Sugarcane(PSB4Y) & 3.76 & 13.00 \\
\hline Sugarcane(PSB21) & 4.46 & 17.00 \\
\hline Rice (PSB25Y) & 4.90 & 14.66 \\
\hline Rice (PSB49W) & 5.15 & 7.33 \\
\hline Rice $\left(\mathrm{PSB}_{50}\right)$ & 3.71 & 11.75 \\
\hline Rice (PSB56) & 3.41 & 45.50 \\
\hline Rice (PSB63) & 3.98 & 59.66 \\
\hline Wheat (PSB24) & 3.77 & 21.08 \\
\hline Wheat (PSB28) & 3.41 & 45.50 \\
\hline Wheat (PSB29Y) & 4.49 & 7.33 \\
\hline Toria (PSB5W) & 4.86 & 59.16 \\
\hline Toria (PSB30Y) & 3.63 & 13.50 \\
\hline Toria (PSB59) & 3.86 & 13.83 \\
\hline
\end{tabular}

Source: Nath et al., 2010 
Table.13 Variability in P solubilization of different inorganic phosphorus sources by F1 and F4 at different periodic intervals

\begin{tabular}{|c|c|c|c|c|}
\hline \multirow{2}{*}{$\begin{array}{l}\text { Incubation } \\
\text { period }(d)\end{array}$} & \multicolumn{4}{|c|}{$\%$ P solubilized } \\
\hline & TCP & $\mathbf{R P}$ & FP & $\mathbf{A P}$ \\
\hline \multicolumn{5}{|c|}{$F_{1}$ (A. niger) } \\
\hline 4 & 26.94 & 2.86 & 2.18 & 4.66 \\
\hline 7 & 11.5 & 3.72 & 6.74 & 7.33 \\
\hline 11 & 17.6 & 4.00 & 3.97 & 8.48 \\
\hline 15 & 42.5 & 3.24 & 5.14 & 5.34 \\
\hline \multicolumn{5}{|c|}{$\mathbf{F}_{4}$ ( T. harzianum) } \\
\hline 4 & 7.66 & 0.30 & 0 & 0 \\
\hline 7 & 13.74 & 2.34 & 8.40 & 1.10 \\
\hline 11 & 20.79 & 1.10 & 10.00 & 1.18 \\
\hline 15 & 38.32 & 0 & 6.30 & 1.83 \\
\hline
\end{tabular}

Source: Sunita (2016)

Table.14 Per cent $\mathrm{P}$ solubilized from complex $\mathrm{P}$ sources by pure organic acids

\begin{tabular}{|l|c|c|c|c|}
\hline Acids & TCP & RP & FP & AP \\
\hline Succinic $\left(\mathbf{F}_{\mathbf{1}}\right)$ & 9.73 & 1.08 & 1.03 & 1.59 \\
\hline Formic $\left(\mathbf{F}_{\mathbf{1}}\right)$ & 11.66 & 2.14 & 1.35 & 1.49 \\
\hline Citric $\left(\mathbf{F}_{\mathbf{4}}\right)$ & 13.62 & 2.62 & 14.44 & 4.24 \\
\hline Malic $\left(\mathbf{F}_{\mathbf{4}}\right)$ & 18.78 & 2.11 & 5.41 & 2.75 \\
\hline Acetic $\left(\mathbf{F}_{\mathbf{4}}\right)$ & 5.41 & 0.87 & 2.00 & 1.74 \\
\hline Propionic $\left(\mathbf{F}_{\mathbf{4}}\right)$ & 4.06 & 1.08 & 1.59 & 1.40 \\
\hline
\end{tabular}

Source: Sunita (2016)

Table.15 Effect of rock phosphate and phosphate solubilizers on P content, Uptake of Soybean

(Value in parentheses indicates $\mathrm{P}$ content)

\begin{tabular}{|l|c|c|c|c|}
\hline \multirow{2}{*}{ P sources } & \multicolumn{4}{|c|}{ Phosphate solublizers } \\
\cline { 2 - 5 } & \multicolumn{2}{|c|}{ P content (mg P/g dry matter) and uptake (mg P /pot) } \\
\cline { 2 - 5 } & Aa & Ps & Bp & Mean \\
\hline Udaipur & $(3.9) 28.1$ & $(3.4) 22.9$ & $(3.0) 20.8$ & $(3.4) 23.4$ \\
\hline Mussoorie & $(4.1) 31.7$ & $(3.3) 26.2$ & $(2.6) 18.6$ & $(3.3) 25.5$ \\
\hline Jhabua & $(3.3) 21.8$ & $(2.7) 19.5$ & $(2.3) 14.0$ & $(2.7) 18.4$ \\
\hline N. Carolina & $(3.7) 29.8$ & $(3.8) 29.3$ & $(3.9) 23.7$ & $(3.5) 27.6$ \\
\hline TSP & $(4.7) 38.2$ & $(4.1) 33.1$ & $(4.0) 28.4$ & $(4.1) 33.2$ \\
\hline Mean & $(3.8) 29.9$ & $(3.5) 20.2$ & $(3.1) 20.8$ & \\
\hline
\end{tabular}

Source: Narayanasamy, 1999 
Fig.A Water-soluble P concentrations $1.9 \mathrm{~cm}$ to the side of a MAP fertilizer band, uncoated (control) or coated with a humic acid product (HA 1 or HA 2). The prefertilization sample (pre) was collected less than $1 \mathrm{~h}$ prior to fertilization. Significant difference from control (P $1 / 40.05)$.

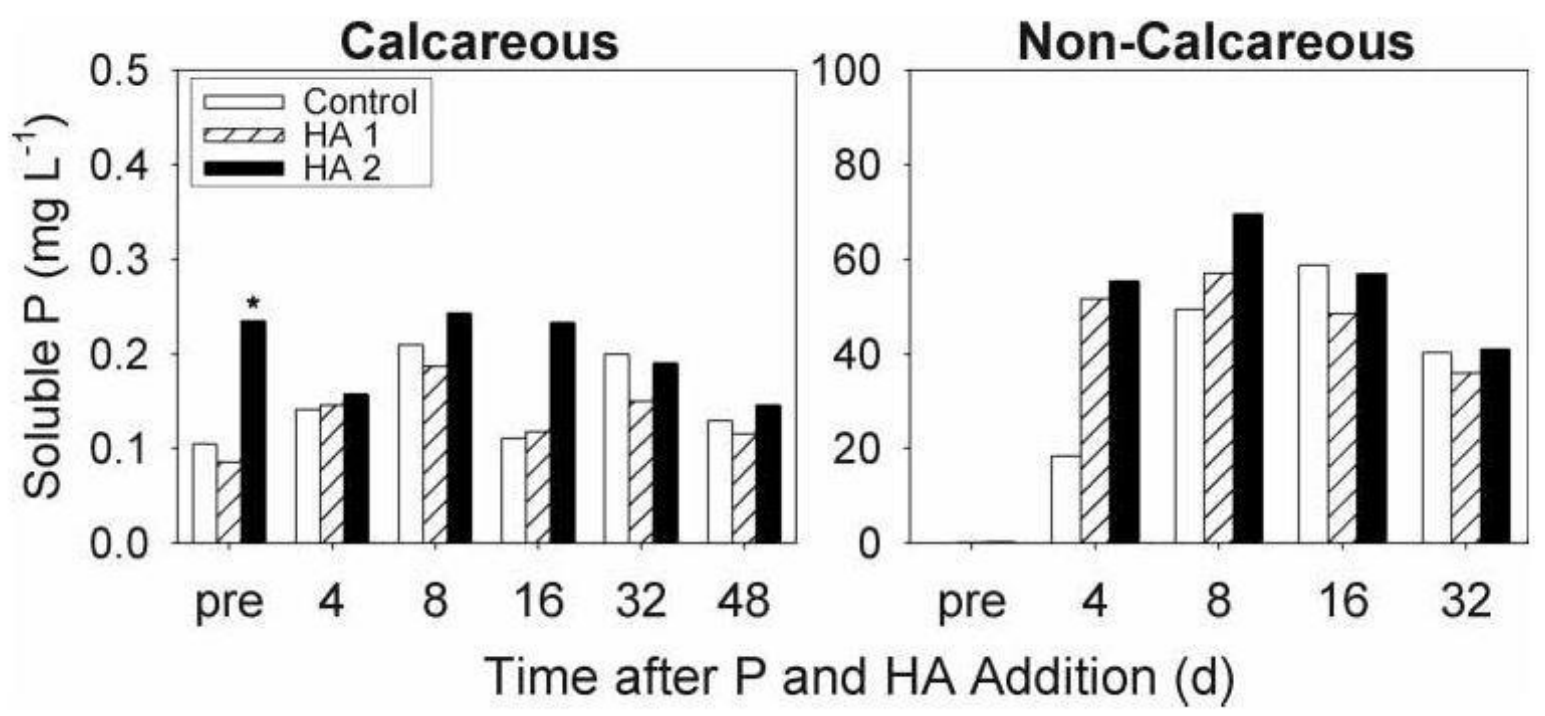

Source: Jones et al., (2007)

Fig.B Longer root hairs improve phosphorus acquisition in the presence and absence of mycorrhizal inoculation in common bean (Phaseolus vulgaris L.). Plants were grown for 28 days in low-P soil with (+VAM) or without (-VAM) mycorrhizal inoculum. Genotypes are recombinant inbred lines having long or short root hairs

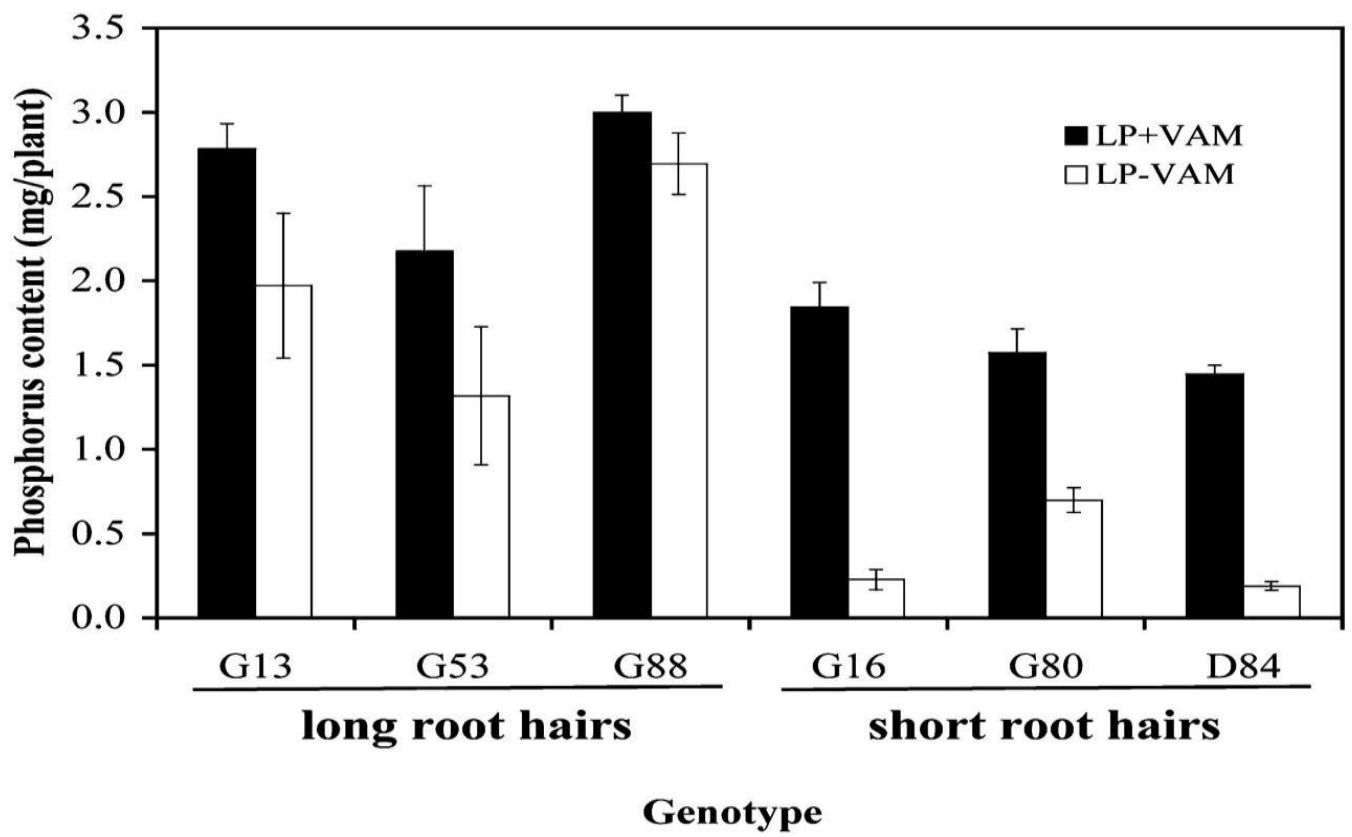


Fig.C. Influence of P concentration of shoots on exudation of organic acids of 20 days old sugar beet plants

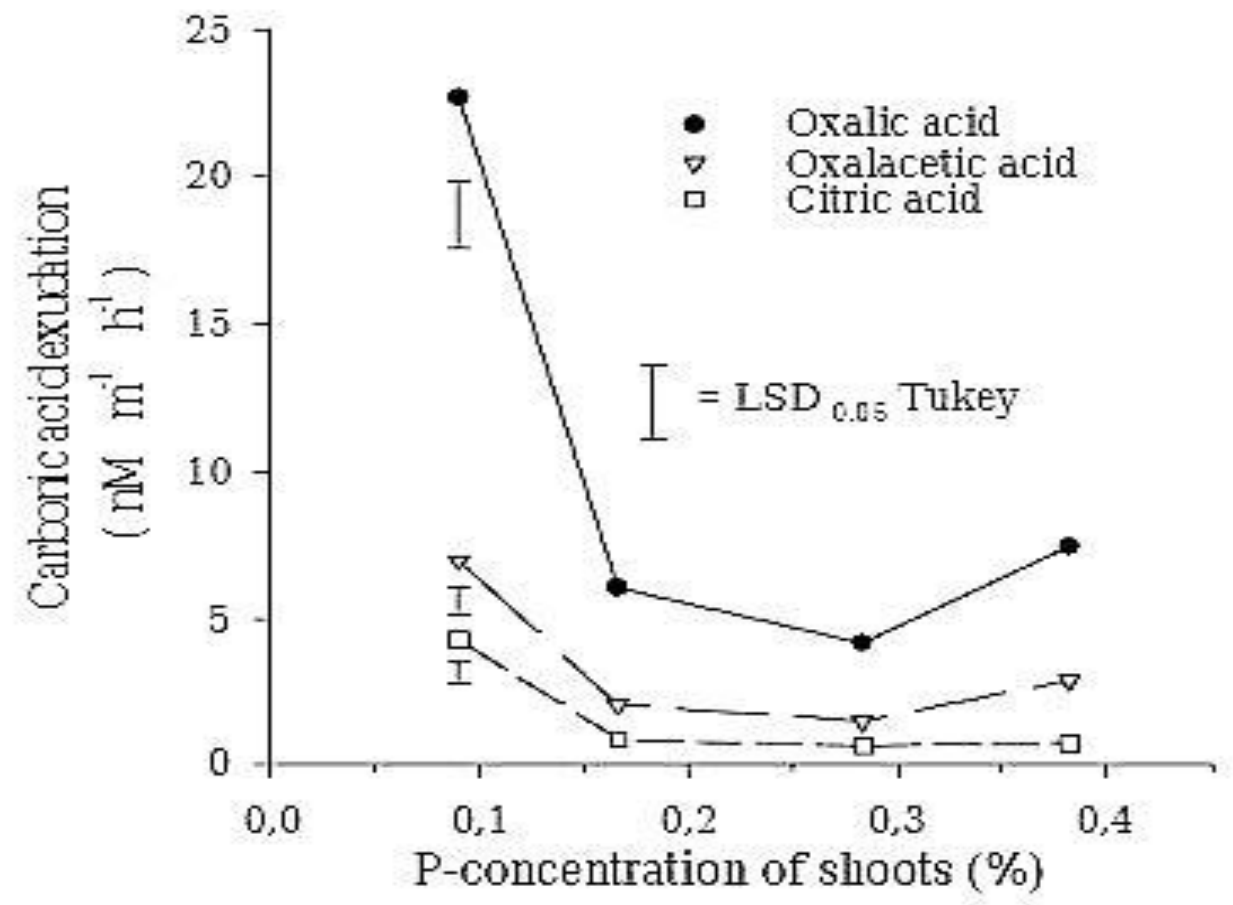

Fig.D Total $\mathrm{P}$ concentration in the shaking solution

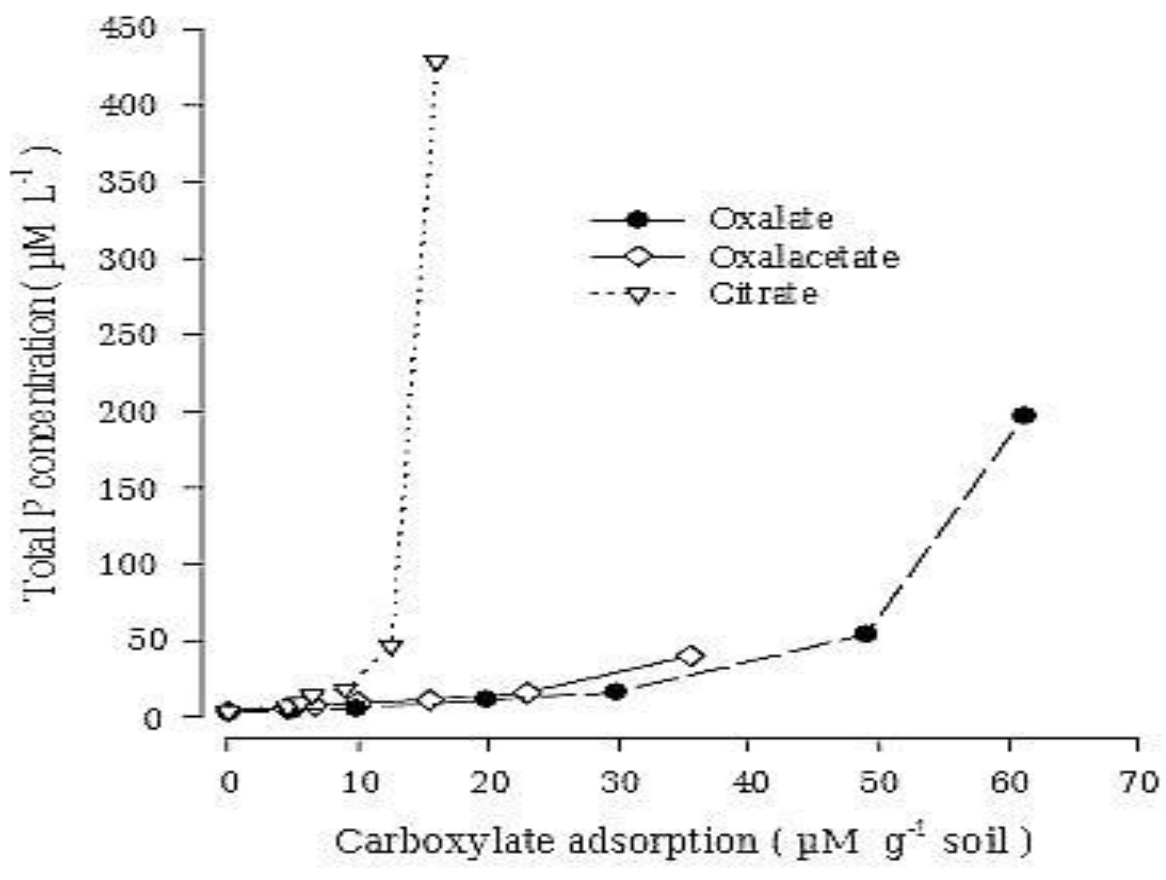


Fig.E Influence of acid mixtures (molar ratio 1:0.35:0.15) and $\mathrm{HCl}$ on $\mathrm{pH}$ and $\mathrm{P}$ release of soil (silty loam)

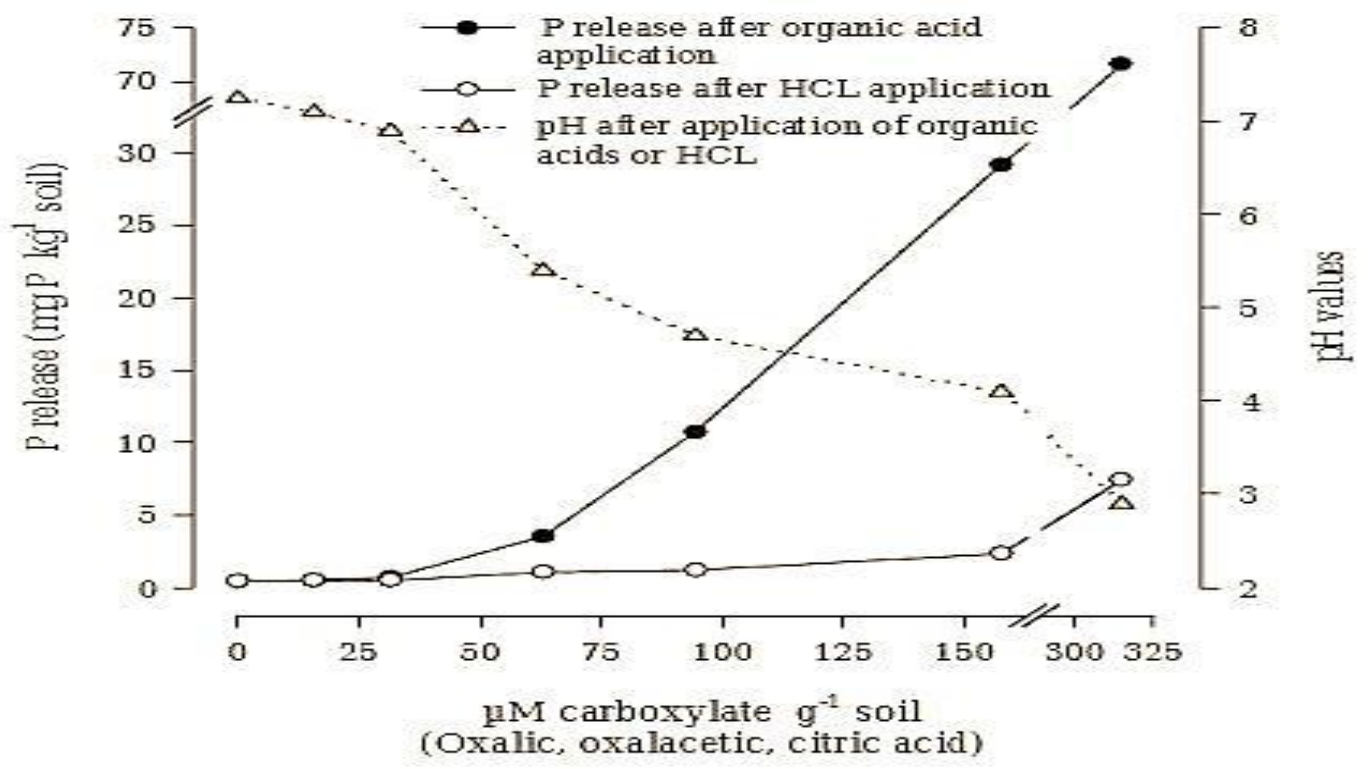

Source: Beissner et al., (2015).

Fig.F Average P fractions as affected by growth of ruzigrass or soil kept fallow during the soybean off-season in four soil layers

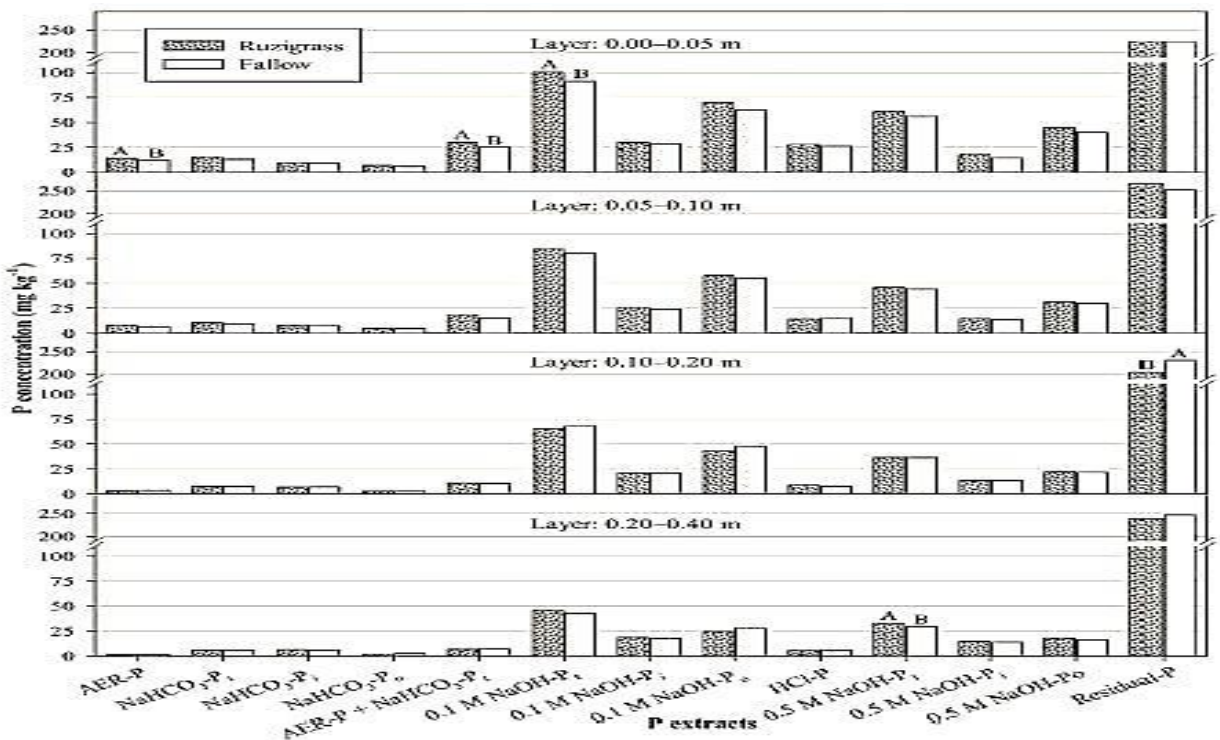

Source: Almeida et.al. (2016)

The per cent solubilization of TCP in the medium, ranged from 11.75 to 59.66 with significant variation among the isolates. Out of 13 isolates, $\mathrm{PSB}_{63}$ (Rice rhizosphere) and $\mathrm{PSB}_{5 \mathrm{w}}$ (Toriarhizosphere) were excellent Psolubilizer with maximum drop of $\mathrm{pH}$ to 3.98 
and 4.86 respectively, that significantly differed from all other isolates. These isolates showed maximum solubilization of TCP to the tune of 59.6 and $59.16 \%$, respectively. On the other hand, the isolate $\mathrm{PSB}_{49 \mathrm{w}}$ (Rice rhizosphere) could solubilize $7.33 \% \mathrm{P}$ with drop of $\mathrm{pH}$ (5.15) in the medium being relatively higher 1.49 (units).Differences in inorganic $\mathrm{P}$ solubilizing abilities by 13 PSB isolates from four crop rhizospheres might be due to its genetic traits.

\section{Effect of phosphate dissolving fungi on $P$ availability}

Aspergillus niger and Trichoderma harzianum used in the study were isolated from the rhizosphere of soybean and compost respectively. The quantity of TCP, Rock phosphate, Ferric phosphate and Aluminium phosphate used is $5 \mathrm{~g} / \mathrm{lit}$.

The quantity of soluble $\mathrm{P}$ in cell free culture filtrate at different periodic intervals is given in Table 12. The results showed that $\mathrm{P}$ source affected the amount of $\mathrm{P}$ solubilized by test fungi. Both fungi exhibited their highest potential to release $\mathrm{P}$ from TCP compared to other P sources tested (Table 12). F1 was more efficient to demonstrate its maximum solubilization of TCP $(42.5 \%)$ on 15thday, followed by AP ( $8.48 \%$ on 11th day), FP (6.74\% on 7 th day) and RP $(4.00 \%$ on 11 th day) than F4 that solubilized TCP to the extent of $38.3 \%$ on 15 th day, FP $(10.0 \%$ on 11 th day) and AP equivalent to1.83\% on 15 th day, but was unable to release $\mathrm{P}$ from RP in solution with $1 \%$ glucose concentration in medium. TCP solubilization pattern of F1 was not linear as initial higher release of $\mathrm{P}$ $(26.94 \%)$ on 4thday was followed by a decline on 7 th and 11th day of incubation (11.58 and $17.69 \%$ respectively), with substantial increase to $42.5 \%$ on 15 th day. Contrarily, F4 showed a gradual increase in soluble Ca-P content with progressive incubation and also exhibited its higher potential to dissolve FP compared to RP and AP (Table 12).

Both test fungi (F1 and F4) produced different organic acids during solubilization of TCP and RP. Succinic and formic acid were detected in culture filtrate of F1 with TCP as $\mathrm{P}$ source where as citric acid was detected in filtrate of F4 with the same $\mathrm{P}$ source. F4 produced propionic and acetic acid and malic acid.

The perusal of data on solubilization of various insoluble phosphates by pure organic acids revealed that relative efficiency of tested organic acids to bring $\mathrm{P}$ in to solution varied among themselves. Malic acid was most competent to solubilize TCP followed by citric, formic and succinic, RP was the least solubilized $\mathrm{P}$ source by all the tested organic acids and citric acid was most efficient acid to release $\mathrm{P}$ from RP, FP and AP (Table 13).

\section{Direct effect of Rock phosphates and Phosphate Solubilizers on soybean growth}

The Experiment was conducted to evaluate the direct effect of low grade rock phosphate and TSP along with phosphate solublizer. Phosphate solublizer Aspergillus awamori, Pseudomonas striata and Bacillus polymyxa were used.

The data presented in the table: 14 show that the mean values of two levels of phosphatic source had significant effect on the P content and its uptake by soybean shoots. The treatment containing North Carolina rock phosphate had significant effect on $\mathrm{P}$ content with $3.5 \mathrm{mg} P$ per gram dry matter yield and on $\mathrm{P}$ uptake with $27.6 \mathrm{mg} \mathrm{P}$ per pot over other phosphatic treatments. However, among the Indian rock phosphate the performance of Mussoorie rock phosphate on uptake was 
greater than Udaipur. But, TSP treatment gave the highest value of $\mathrm{P}$ concentration in tissue and total $\mathrm{P}$ uptake (33.2 $\mathrm{mg} \mathrm{P}$ per pot) of soybean. This could be due to easy availability of $\mathrm{P}$ from TSP when compared to other sources of $P$. significant effect of phosphate solubilizers was also noticed on the $\mathrm{P}$ concentration and the uptake. Interaction between $\mathrm{P}$ sources and PSM had significant effect on $\mathrm{P}$ uptake. The performance of Mussoorie RP with A. awamori and P. striata was superior to Udaipur and Jhabua RP when applied with PSM. Between phosphate solubilizers, A. awamori proved to be superior with values of $3.8 \mathrm{mg} \mathrm{P}$ /gram dry matter as $\mathrm{P}$ content and $29.9 \mathrm{mg} \mathrm{P}$ per pot its uptake over other solubilizers.

Conclusions of the study are as follows:

Application of FYM along with inorganic fertilizers improved the soil available P status.

Combined use of inorganic and organic fertilizers (like FYM) along with PSB(Pseudomonas) increases availability of $\mathrm{P}$ in soil by solubilization, mobilization \& native build of $\mathrm{P}$ in soil and reduces $\mathrm{P}$ fixation with $\mathrm{Fe}, \mathrm{Al} \& \mathrm{Ca}$.

Increase activity of phosphatase enzyme through conjuctive use of phytase \& FYM can increase the availability of phosphorus.

$\mathrm{P}$ solubilizing rhizospheric bacteria can be used for improving $\mathrm{P}$ solubilization in moderate to strongly acidic condition.

Amendment (Pressmud \& Lime) can use in strongly acidic condition to improve solubilization of $\mathrm{P}$.

Dual inoculation with (rhizobium and VAM) increase rhizosphere which increase the solubilization of $\mathrm{P}$
Root exudates (organic acids)improve solubility of phosphatic fertilizers

Cropping sequence with legumes are effective to solubilization of phosphorus

\section{Future perspectives}

The research was driven by environmental concerns about the high $\mathrm{P}$ status of many fertilized soils and the resulting nutrient pollution of receiving watercourses.

Development of satisfactory technology to enhance the efficiency of $\mathrm{P}$ fertilizer application

Sustainable use of legacy soil $\mathrm{P}$

\section{References}

Abelson PH (1999) A potential phosphate crisis. Science 283:2015.

Almeida DS, Rosolem CA (2016) Ruzigrass grown in rotation with soybean increase soil labile phosphorus.Agron J 108: 2444-2452

Almeida, J.A., J. Torrent, and V. Barrón. 2003. Cor de solo, formas do fósforo e adsorção de fosfatosem Latossolosdesenvolvidos de basalto do extremo-sul do Brasil. Rev. Bras. Cienc. Solo 27:985-1002. doi:10.1590/S010006832003000600003

Beissner Lutz, RomerWilhelm Mobilization of phosphorus by root exudates of sugar Beet Poster presentation Institutfür Agrikulturchemie, Von-Siebold-Str. 6, D 37075 Göttingen, Germany.

Brown L,George T, DupuyL, White P (2013) Aconceptualmodel of root hair ideotypes for future agricultural environments: what combination of traits should be targeted to cope with limited $P$ availability? Ann Bot 112:317-330 
Carvalhais, L.C., Dennis, P.G. Fedoseyenko, D., Hajirezaei, M.R., Borriss, R. and Wiren, N.V. (2011) Root exudation of sugars, amino acids, and organic acids by maize as affected by nitrogen, phosphorus, potassium, and iron deficiency. Journal of Plant Nutrition and Soil Science 174, 3-11.

Clain A. Jones , Jeffrey S. Jacobsen \& Aaron Mugaas, Effect of Low- Rate Commercial Humic Acid on Phosphorus Availability, Micronutrient Uptake, and Spring Wheat Yield Communications in Soil Science and Plant Analysis, 38:7-8, 921-933, DOI: 10.1080/00103620701277817

Condron LM Turner, Turner BL, CadeMenun BJ (2005) Chemistry and dynamics of soil organic phosphorus, In: Sims JT, Sharpley AN (eds) Phosphorus: agriculture and the environment, Agronomy monograph, vol 46. ASA-CSSA-SSSA, Madison, pp. 87-121. doi:10.2134/agronmonogr46.c4.

Cordell D, Drangert J-O, White S (2009) The story of phosphorus: global food security and food for thought. Glob Environ Chang 19: 292-305.

Cordell D, White S (2014) Life's bottleneck: sustaining the world's phosphorus for a food secure future. Annu Rev Environ Resour 39:161-188.

Datta, S.C., M.L. Dotaniya, D.R. Biswas and Kuldeep Kumar (2014) Effect of Organic Sources onPhosphorus Fractions and Available Phosphorus in TypicHaplustept. Indian Society of Soil Science, 62(1): 80-83.

Danilo S. Almeida and Ciro A. RosolemRuzigrass Grown in Rotation with Soybean Increases Soil Labile Phosphorus Agronomy Journal. Vol. 108

Das, P.K., Sethi, A.K., Jena, M.K., Patra, R.K. Effect of $\mathrm{P}$ sources and Dual
Inoculation of VAM and Rhizobium on dry matter yield and nutrient Uptake by Green Gram Journal of the ISSS, Vol. 47, No.3, pp 466-470 (1999)

Dasog, G.S., Patil, P.L., Gali, S.K., Effect of of Groundnut Genotypes, Lime and Phosphorus Levels on the transformation of Phosphorus in Lowland Acidic Soils of Coastal Agroeco-system of Karnataka, J ISSS, Vol. 58, No. 2, pp 182-188 (2010).

DattaAshim, Paul Niladri, GiriUtpalSahaDipankar Effect of Organic matter vis-à-vis Humic acid on Phosphorus availability of RiceMustard cropping sequence Journal of the ISSS, Vol. 65, No. 2, pp 210-221 (2017)

Dixit, S.P., Sharma, P.K. (2003) Effects of Phosphorus and lime on productivity, phosphorus uptake by Onion in a Typic Haplustalf of Himachal Pradesh. Indian Journal of Agricultural Sciences 74,479-481.

Dotaniya, M.L., Datta, S.C., Biswas, D.R., Kuldeepkumar, Effect of Organic Sources on Phosphorus Fractions and Available Phosphorus in TypicHaplustept, Journal of the ISSS, Vol. 62, No. 1, pp 80-83 (2014).

Fox RL, Kamprath E (1970) Phosphate sorption isotherms for evaluating the phosphate requirements of soils. Soil SciSoc Am J 34: 902-907.

Giles CD, Cade-Menun BJ, Liu CW, Hill JE (2015) The shortterm transport and transformation of phosphorus species in a saturated soil following poultry manure amendment and leaching. Geoderma 257:134-141.

Giles CD et al., (2016) Does the combination of citrate and phytase exudation in Nicotiana tabacum promote the acquisition of endogenous soil organic phosphorus? Plant Soil 412:1-17.

Giles CD et al., (2017). Linking the depletion 
of rhizosphere phosphorus to the heterologous expression of a fungal phytase in Nicotiana tabacum as revealed by enzyme-labile $\mathrm{P}$ and solution $31 \mathrm{P}$ NMR spectroscopy. Rhizosphere 3:82-91

Grossl, P.R. and Inskeep, W.P. (1991) Precipitation of dicalcium phosphate dehydrate in the presence of organic acids. Soil Science Society of America Journal, 55: 670-675.

Grossl, P.R. and Inkseep, W.P. (1992) Kinetics of octacalcium phosphate crystal growth in the presence of organic acids. Geochimicaet CosmochimicaActa, 56: 1955-1961.

Guo, F., and R.S. Yost. 1998. Partitioning soil phosphorus into three discrete pools of differing availability. Soil Sci. 163:822833.

Guppy C, Menzies N, Moody P, Blamey F (2005) Competitive sorption reactions between phosphorus and organic matter in soil: a review. Soil Res 43:189-202.

Haynes, R.J. (1992) Effects of Liming on phosphate availability in acid soils.Plant and Soil 68, 289-308.

Illmer, P. and Schinner, F. (1992) Solubilization of inorganic phosphates by microorganisms isolated from forest soils. Soil Biology and Biochemistry 24, 389-395.

Irshad U, Brauman A, Villenave C, Plassard C (2012) Phosphorus acquisition from phytate depends on efficient bacterial grazing, irrespective of the mycorrhizal status of Pinuspinaster. Plant Soil 358:155-168.

Jadhav, A.B., Suradkar, Rahul, Barbie Taggu, Tamboli, B.D., Priyanka, B. (2017). Effect of Phytase and FYM on Soil Enzyme Activities, Microbial Population and Nutrient Availability of Non-Calcareous Soil. Journal of the ISSS, Vol. 65, No. 2, pp 222-229.

Jonathan Paul Lynch Magalhaes Amade
Miguel, Johannes AukePostmaPhene Synergism between Root Hair Length and Basal Root Growth Angle for Phosphorus Acquisition1 Plant Physiology_, April 2015, Vol. 167, pp. 1430-1439

Kabba, B.S. and Aulkah, M.S. (2004) Climatic conditions and crop residue quality differentially affect, $\mathrm{N}, \mathrm{P}$ snd $\mathrm{S}$ mineralization in soils with contrasting $\mathrm{P}$ status. Journal of Plant Nutrition and soil science 167, 596-609.

Kamprath E (1967) Residual effect of large applications of phosphorus on high phosphorus fixing soils. Agron J 59:2527.

Menezes-Blackburn D et al., (2016b) Organic acids regulation of chemical-microbial phosphorus transformations in soils. Environ SciTechnol 50:11521-11531.

Narayanasamy G., Qureshi A. Direct effect of Rock phosphates and Phosphate Solubilizers on soybean growth in a TypicUstochrept Journal of the ISSS, Vol. 47, No. 3, pp 475-478 (1999).

Nath, D.J., Baruah, R., Ozah, B., Kalita, N. Delineation of Phosphate Solubilizing Bacteria from Rhizosphere of Different Crops of Assam Journal of the ISSS, Vol. 58, No. 4, pp 403-408 (2010).

Owen D, Williams A, Griffith G, Withers P (2015) Use of commercial bioinoculants to increase agricultural production through improved phosphrous acquisition. Appl Soil Ecol 86: 41-54.

Pavinato, P.S., A. Merlin, and C.A. Rosolem. 2009. Phosphorus fractions in Brazilian Cerrado soils as affected by tillage. Soil Tillage Res. 105:149-155.

Pritpalsingh, Hargopalsingh and G.S. Bahl (2010). Phosphorus Supplying Capacity of Pressmud amended-Recent Floodplain Soils under Different Moisture Regimes, Indian Society of Soil Science, vol. 58, No.2, pp. 168- 
181.

Raboy V (2001) Seeds for a better future: 'lowphytate' grains help to overcome malnutrition and reduce pollution. Trends Plant Sci 6:458-462 Raboy V (2002) Progress in breeding low phytate crops. J Nutr 132:503S-505S

Redel, Y.D., R. Rubio, J.L. Rouanet, and F. Borie. 2007. Phosphorus bioavailability affected by tillage and crop rotation on a Chilean volcanic derived Ultisol. Geoderma 139:388-396.

Sattari SZ, Bouwman AF, Giller KE, van Ittersum MK (2012) Residual soil phosphorus as the missing piece in the global phosphorus crisis puzzle. ProcNatlAcadSci 109:6348-6353.

Singh P, Singh H, Bahl G.S. (2010) Phosphorus Supplying Capacity of Pressmud amended Recent Floodplain Soils under Different Moisture Regimes J ISSS, vol.58 No.2, pp 168-181.

Solanky, B.S., Verma, G.P., Motiramani, D.I. (1971) Effect of liming on the availability of Plant nutrients in acid soils. Maysore Journal of Agricultural Sciences 5,145-149.

Sunita Gaind. Phosphate dissolving fungi: Mechanism and application in alleviation of salt stress in wheat Microbiological Research 193 (2016)
94-102.

Stutter MI et al., (2012) Recovering phosphorus from soil: a root solution? Environ SciTechnol 46:1977-1978.

Syers, J.K., A.E. Johnston, and D. Curtin. 2008. Efficiency of soil and fertilizer phosphorus use. Rome, FAO.

Trouillefou CM, Le Cadre E, Cacciaguerra T, Cunin F, Plassard C, Belamie E (2015) Protected activity of a phytase immobilized in mesoporous silica with benefits to plant phosphorus nutrition. J Sol-Gel SciTechnol 74:55-65

Vance CP, Uhdestone C, Allan DL (2003). Phosphorus acquisition and use: critical adaptations by plants for securing a nonrenewable resource. New Phytol 157: 423-447

Wang, T.S.C., SAN-Yae Cheng and Tung, H. (1967) Dynamics of soil organic acids. Soil Science 104, 138-144.

Yadvinder-Singh, Bijay-Singh, Maskina, M.S. and Meelu, O.P. (1988) Effect of organic manures, crop residues and green manures (Sesbania aculeata) on nitrogen and phosphorus transformation in a sandy loam soil at field capacity and under waterlogged conditions. Biology and fertility of soils 6, 183-187

\section{How to cite this article:}

Narendra Kumar Yadav and Rajat Kumar Parit. 2020. Opportunities for Mobilizing Recalcitrant Phosphorus- A Review. Int.J.Curr.Microbiol.App.Sci. 9(02): 1735-1756. doi: https://doi.org/10.20546/ijcmas.2020.902.199 